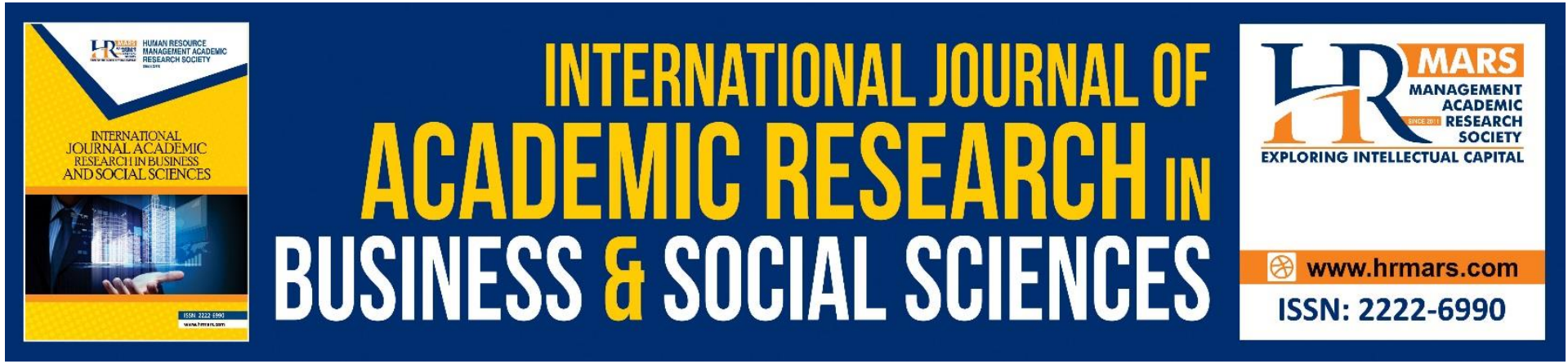

\title{
The Application of UTAUT Theory to Determine Factors Influencing Malaysian Adoption Mobile Banking
}

Tan, M. C., Zariyawati, M. A. \& Hirnissa, M. T.

To Link this Article: http://dx.doi.org/10.6007/IJARBSS/v11-i1/8448 ～DOI:10.6007/IJARBSS/v11-i1/8448

Received: 10 November 2020, Revised: 08 December 2020, Accepted: 01 January 2021

Published Online: 15 January 2021

In-Text Citation: (Tan et al., 2011)

To Cite this Article: Tan, M. C., Zariyawati, M. A., \& Hirnissa, M. T. (2011). The Application of UTAUT Theory to Determine Factors Influencing Malaysian Adoption Mobile Banking. International Journal of Academic Research in Business and Social Sciences, 11(1), 146-159.

Copyright: (c) 2021 The Author(s)

Published by Human Resource Management Academic Research Society (www.hrmars.com)

This article is published under the Creative Commons Attribution (CC BY 4.0) license. Anyone may reproduce, distribute, translate and create derivative works of this article (for both commercial and non-commercial purposes), subject to full attribution to the original publication and authors. The full terms of this license may be seen at: http://creativecommons.org/licences/by/4.0/legalcode

Vol. 11, No. 1, 2021, Pg. 146 - 159

http://hrmars.com/index.php/pages/detail/IJARBSS

JOURNAL HOMEPAGE

Full Terms \& Conditions of access and use can be found at http://hrmars.com/index.php/pages/detail/publication-ethics 


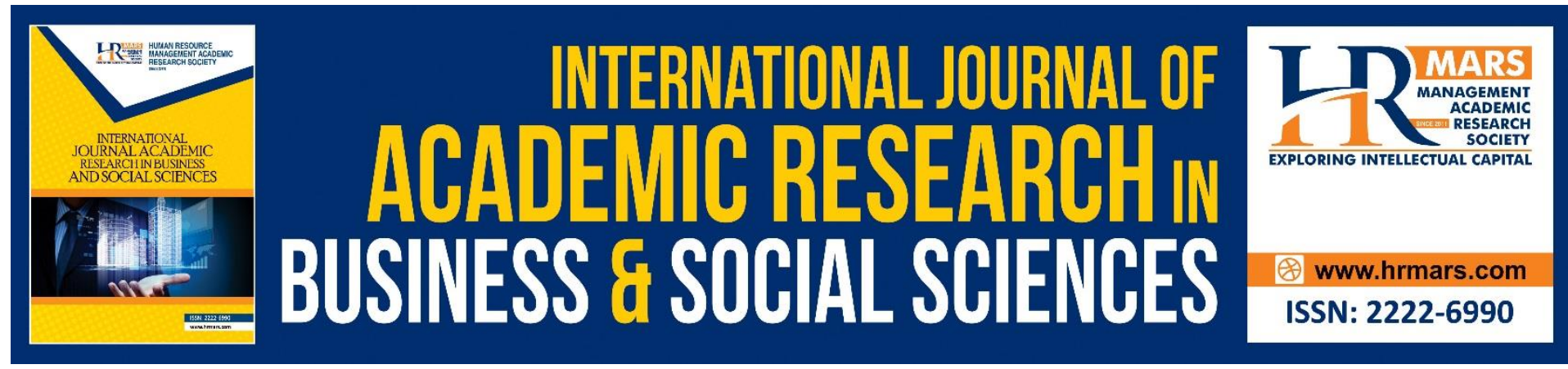

\title{
The Application of UTAUT Theory to Determine Factors Influencing Malaysian Adoption Mobile Banking
}

\author{
Tan, M. C., Zariyawati, M. A. \& Hirnissa, M. T. \\ School of Business and Economics, Universiti Putra Malaysia, Kolej Universiti Poly-Tech Mara, \\ Malaysia
}

\begin{abstract}
Mobile banking refers to use of mobile devices such as a smartphone or tablet to conduct financial transactions and services remotely. However, mobile banking adoption rate in Malaysia are relatively low. The purpose of this study is to investigate the factors influence mobile banking adoption in Malaysia context using UTAUT theory with an extension of "trust" variable. The data of this study was collected from primary sources through online questionnaire. Findings denoted that performance expectancy (PE), effort expectancy (EE), social influence $(\mathrm{SI})$ and trust $(\mathrm{T})$ have significant influences towards behavioural intention (BI) of mobile banking adoption (MBA). Thus, banks are recommended to look into these factors in encouraging mobile banking adoption in Malaysia.
\end{abstract}

Keywords: Mobile Banking, UTAUT, Performance Expectancy (PE), Effort Expectancy (EE), Social Influence (SI), Trust (T), Behavioural Intention (BI), Malaysia

\section{Introduction}

Mobile banking refers to use of mobile devices such as smartphone or tablet to conduct financial services remotely. Banking services like transactions between accounts, access account information, bill payment and others are provided by bank or financial institution through mobile banking to ensure basic banking services are accessible by customers all the time at their will. Mobile banking are getting more popular as it help users save a lot of time by avoiding queue for one particular services in banks that congested with customers. Banks also able to save and cut off some administration costs in by managing lesser physical branches through mobile banking.

As the society is going cashless and the usage of mobile phone is emerging, mobile banking adoption (MBA) around the world is growing accordingly along with the trends. In $2016,47 \%$ of users in Europeans countries are adopting mobile banking as their payment alternatives and $16 \%$ of users are expected to adopt mobile banking in coming year (ING International Survey Mobile Banking, 2016). In 2017, telecommunications corporation, Orange has launched its own $100 \%$ mobile- based bank where all banking services would be offered and conducted via mobile devices (CNBC, 2017). All these depicted that mobile banking is growing tremendously in banking industry.

However, this situation happened in Malaysia differently. On the report of official portal of Department of Statistics Malaysia, Malaysia achieved 97.5\% of mobile phone users in 2015. Hence, 
banks in Malaysia have started their investment in mobile banking applications since 2015 (HSBC, Malay Mail). About 17 out of 30 banks and financial institutions in Malaysia have adopted and offered mobile banking services (Bank Negara Malaysia, 2017). Even more than half of banks and financial institution invested substantially in mobile banking, adoption rate of mobile banking in Malaysia population still relatively low. In 2017, there are just $36.3 \%$ of population are mobile banking users (Payment Statistics of Bank Negara Malaysia, 2018).

There are several influencing factors in these issues. Mobile banking apps such as Maybank2u, $C I M B$ Clicks and iRakyat has been review as buggy apps where app often break down and caused difficulties in logging in, website freeze and most importantly unable to perform transaction at users' will (Google Play, 2017). Then, installation of mobile banking applications would lower down memory of mobile device. Complicated procedure of syncing phone with bank account and entire process of experiencing mobile banking discourage MBA. People tend to follow trends and influenced by people surrounded such as friends, families, relative and reference groups as they want to be involved in society (Alalwan et. al, 2017). Therefore, low MBA rate, $36.3 \%$ among population in Malaysia caused passive MBA. Furthermore, trust has been widely tested and proven to be a crucial factor towards mobile banking adoption (Masrek et al., 2014). Users lack of trust to sync personal financial data with mobile banking applications and fear of privacy breach across telecommunication network. In 2018, Android Malware attacked targets on Asia smartphone users through mobile banking and popular game applications (Kaspersky Lab, 2018). All these personal data leakage and security issues influence discourage users' trust towards MBA in Malaysia. Therefor the objective of this study as below:-

i) to investigates factors that influence mobile banking adoption (MBA)

ii) to understand Malaysian's perception towards adoption of mobile banking as banking alternatives.

\section{Literature Review}

Unified Theory of Acceptance Use of Technology (UTAUT) is technology adoption model that explain the degree of acceptance of the use of information technology (Venkatesh et al., 2003). Venkatesh and others founded UTAUT by combining 8 prior technology adoption model including Theory of Reasoned Action (TRA), Technology Acceptance Model (TAM), Theory of Planned Behaviour (TPB), Innovation Diffusion Theory (IDT), Social Cognitive Theory (SCT), Motivational Model (MM), combined TAM and TPB (C-TAM-TPB) and Model of Personal Computer Utilization (MPCU). By far, UTAUT is the most comprehensive technology adoption and acceptance model (Sarfaraz, 2017). Initially, there were 7 constructs being included in UTAUT namely performance expectancy (PE), effort expectancy (EE), social influence ( $\mathrm{SI}$ ), facilitating conditions (FC), computer self-efficacy, anxiety, and attitude towards using technology (Venkatesh et. al., 2003). However, only 4 constructs have being proven to be significant, namely performance expectancy (PE), effort expectancy (EE), social influence (SI), and facilitating conditions (FC) that explain the behavioural intention (BI) and actual usage or adoption of specific technology or system (Venkatesh et. al., 2003).

Over the prior researches, Technology Acceptance Model (TAM) appeared to be the most popular model as it is frequently and commonly being used by researchers in investigating mobile banking adoption (Aboelmaged \& Gebba, 2013; Kishore \& Sequeira, 2016). Subsequent well-known predictive models for examination of factors influencing BI of MBA are the Theory of Reasoned Action (TRA), the Theory of Planned Behaviour (TPB), Task Technology Fit (TTF), Diffusion of Technology (Dol), and Theory of Perceived Risk (TPR) (Mahad et. al., 2015; Choudrie et. al., 2017; Shareef et. al., 2018). Although these theories were proven to have significant contributions to the study of MBA, limitations still exist in assessing BI of MBA. First of all, though each theory has owned different terminologies, these terminologies are basically explaining the similar concepts. Limitations from several researchers 
that using theories above do suggested to used more welly extended theory such as UTAUT as it is more comprehensive in examining BI of MBA (Aboelmaged \& Gebba, 2013; Verrisimo, 2016). UTAUT that proposed as an extension of the popular TAM (Davis et. al., 1989) and consolidation of 8 technology adoption model appeared to be the most suitable theory for this study.

In this study, researcher will involve 3 constructs (PE, EE, SI) from UTAUT as they are proven to have significant relationship towards $\mathrm{BI}$ of MBA as well as more relevant in Malaysia context. In addition, trust (T) would be added as extension to UTAUT in Malaysia context as android malware issues where Asia smartphone users being attacked through mobile banking applications that occurred recently in 2018 does upraise the concerns of users towards MBA (Kaspersky Lab, 2018). Hence, researcher believed trust would be an essential factor to be included as extension of UTAUT in assessing BI of MBA. Nevertheless, FC is not relevant in the context of Malaysia as Malaysian do have sufficient infrastructure and resources to adopt mobile banking. This is because the basic infrastructure for MBA is definitely a mobile device and the usage of mobile devices in Malaysia is $97.5 \%$, of which it is a proportionately high number for researchers to include FC as construct (Department of Statistics Malaysia, 2015).

\section{Performance Expectancy (PE)}

Performance Expectancy (PE) is the degree where an individual believes that mobile banking adoption will increase his/her efficiency in performing his/her task (Venkatesh et. al., 2012). In a simpler way, if the user perceived that adoption of particular technology or system able to help he/she complete or perform his/her task in an easier and effective way, user would inclined to adopt the technology or system. According to the previous researches on MBA, PE had being approved as one of the most significant predictors towards BI of MBA for users as well as banking customers (Alalwan et. al., 2017; Sarfaraz, 2017). PE had being validated as one of the strongest predictor together with other constructs explained $61.7 \%$ of variance in behavioral intention of MBA among private universities students (Evon \& Jasmine, 2016). PE also act as vital factor in influencing BI of MBA even for Portuguese that are familiar with mobile banking concept (Oliveira et. al., 2014). Other than that, PE was shown to be the most significant predictors in leading to the $\mathrm{BI}$ of MBA in several countries such as in Thailand (Bhatiasevi, 2015), Mozambique adult population (Baptista \& Oliveria, 2015) and villagers in Karnataka (Kishore \& Sequeira, 2016). Apart from these, a minority of researches found out that PE had insignificant and indirect relationship towards BI of mobile banking adoption (Afshan \& Sharif, 2016; Shaikh et. al., 2018). Generally, most of the researchers that investigated in MBA found out that PE has significant influence in $\mathrm{BI}$ of MBA, thus the first hypothesis $(\mathrm{H} 1)$ of this study being established as:

$\mathrm{H} 1$ : There is a significant relationship between PE and $\mathrm{BI}$ of MBA.

\section{Effort Expectancy (EE)}

EE is defined as ease of use associated with adoption of mobile banking (Shaikh et al. 2018) or effort exerted by individual in order to adopt mobile banking (Evon \& Jasmine, 2017). Users would concern on the effort needed in order to use mobile banking application and the complexity of the process involved such as sync phone number with bank account and thus this would influence $\mathrm{BI}$ of MBA (Aboelmaged \& Gebba, 2013). Based on past researches in MBA, researchers found out that EE appeared to be one of the most crucial element in influencing BI of MBA (Evon \& Jasmine, 2016; Alalwan, 2017; Sarfaraz, 2017). A research in Jordan stated that EE played an especially essential role in affecting mobile banking adoption in the context of elder generation (Choudrie et. al., 2017). For villagers in rural areas of Karnataka, EE has being proved to be important antecedent in affecting BI of 
MBA (Kishore \& Sequira, 2016). Behavioural Intention of MBA in Thailand was shown to be influenced by EE directly (Bhatiasevi, 2015). EE was found to have significant and direct relationship in affecting $\mathrm{Bl}$ at the initial stage of MBA (Shaikh et. al., 2018). Perceived ease of use that found to defined similarly with EE were being reported as noteworthy predictors in predicting behavioural intention towards MBA in Dubai (Aboelmaged \& Gebba, 2013), Portugal (Verrisimo, 2016), and India (Sindhu \& Srivastava, 2018). However, several previous researchers also found out that EE has weak or insignificant relationship towards BI of MBA (Oliveira et al., 2014; Ahmed et. al., 2018). In general, EE is a significant predictors in examining behavioural intention of mobile banking adoption, hence the second hypothesis $(\mathrm{H} 2)$ is being developed as:

$\mathrm{H} 2$ : There is a significant relationship between $\mathrm{EE}$ and $\mathrm{BI}$ of MBA.

\section{Social Influence (SI)}

Social Influence is the degree where individual perceived that important others believe that adoption of a new system is necessary and supported, especially family, friends, colleagues, opinionated leaders and reference group (Malaquias \& Hwang, 2016). Encouragements provided by people surrounding especially important social group as mentioned above would directly contribute to user's BI of MBA (Alalwan et. al., 2017). Over the past researches, SI is found to have inconsistent relationship with behavioural intention of MBA. In high power distant society, SI owned a variance of $15.47 \%$ in the relationship with $\mathrm{BI}$ of $\mathrm{MBA}$ and appeared to be dominant and most persuasive predictors among youth in Bangladesh (Ahmed et al., 2017). Stronger social pressure or trend also proven to lead to higher behavioural intention to adopt mobile banking as payment alternatives in Dubai (Aboelmaged \& Gebba, 2013). Researches regarding user's BI of MBA that had been done among silver surfers in United Kingdom (Choudrie et. al., 2017) and undergraduate students in Brazil (Malaquias \& Hwang, 2016) reported that SI had significant relationship in influencing BI of MBA. In Thailand, female was found to adopt mobile banking willingly due to social influence of their families, peers, and extended relationships (Bhathiasevi, 2015). Apart from that, SI also found to have mild or weak relationship towards BI of MBA (Kishore \& Sequeira, 2016). Several researches does found that SI has no significant relationship in affecting BI of MBA (Baptista \& Oliveira, 2015; Sindhu \& Srivastava, 2018). All in all, SI still appeared as a significant antecedent in assessing BI of MBA and thereby, third hypothesis (H3) is being formed as:

$\mathrm{H} 3$ : There is a significant relationship between $\mathrm{SI}$ and $\mathrm{BI}$ of MBA.

\section{Trust (T)}

Trust being conceptualized as the extent of which users have attitudinal confidence for reliability, credibility, and safety of mobile banking system from the technical, organizational, social, and political standpoints and also from the effective, efficient, prompt, and sympathetic customer service response (Shareef et. al., 2018). Effective real time customer support able to build up trust of user towards BI of MBA (Sarfaraz, 2017). Meanwhile, transaction or personal data leakage issues would hinder trust as well as intention of users towards MBA (Kaspersky Lab, 2018). Research focused on trust towards $\mathrm{BI}$ of MBA has been conducted and proven that trust played a main role in influencing $\mathrm{BI}$ of MBA (Masrek et. al., 2014). Trust also found to be primary driving agent for positive BI of MBA (Afshan \& Sharif, 2016; Choudrie et. al., 2017). Extension of trust with UTAUT theory increase R-Squared to 65\% in the studies of MBA of Jordanian banking customers (Alalwan et. al., 2017). In addition, trust was proven to influence adoption of mobile banking significantly especially at the initial stage of adoption (Shareef et. al., 2018). Users also found to be more motivated and willing to adopt mobile banking if there is service assurance and task optimization (Oliveira et. al., 2014). Both trust and perceived credibility were proven to have high similarity and salient role in the BI of MBA (Baptista \& Oliveira, 2015; Shareef et. al., 2018). Trust also proven to have the capability to help users overcome the fears 
of security or privacy risks and fraudulent activities in the MBA (Sindhu \& Srivastava, 2018). To sum it up, trust is a significant factor in affecting BI of MBA and therefore fourth hypothesis being created as: $\mathrm{H} 4$ : There is a significant relationship between $\mathrm{T}$ and $\mathrm{BI}$ of MBA.

\section{Research Methodology}

This study uses primary data obtained through online questionnaire to acquire the general idea of research. The contents in online questionnaire are properly design for the respondent easy understandable base on research framework in Figure 1. The researcher using IBM Statistical Package for the Social Sciences (SPSS) software to analyse data from the questionnaire. The testing included data screening, missing value, and a normality test. Convenient sampling technique will be used for data collection as researcher unable to obtain the complete list of mobile banking user. Sample of this study will include Malaysian that aged 18 years old and above as they are perceived as those who had ability to perform financial related services. According to Krejcie and Morgan (1970), this study

Figure 1 : Research Framework

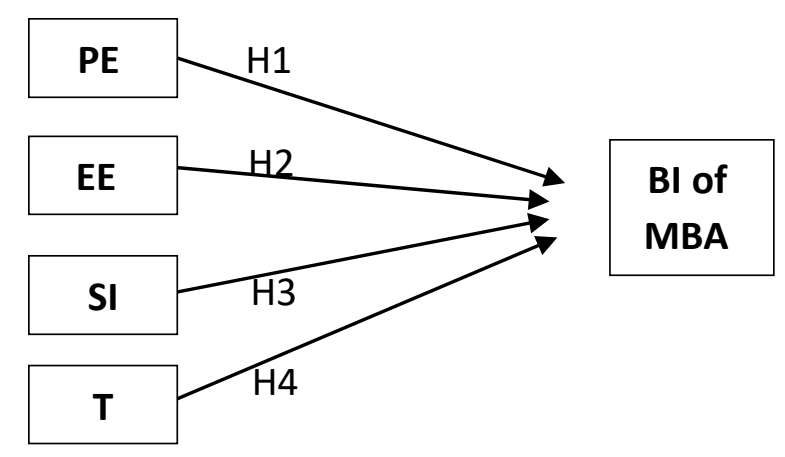

required to take 384 sample size respondent to gain generalizable response.

\section{Results and Findings}

A total number of 424 respondents had took part in this research study. Researcher analyzed the collected data by using Statistical Package for the Social Sciences (SPSS) software to study the validity of hypotheses. The results of analyses will be presented in the form of charts and tables to ease the readings. Several analyses and tests had been conducted including Common Method Variance, Frequency Analysis, Reliability test, Descriptive Analysis and Normality test to ensure the data collected are valid. Finally, Multiple Regression Analysis would be carried out to examine the relationship of each hypotheses. Frequency analysis has been done to further understand demographic profile of respondents. Table below shown the demographic info of respondents: 
INTERNATIONAL JOURNAL OF ACADEMIC RESEARCH IN BUSINESS AND SOCIAL SCIENCES Vol. 11, No. 1, 2021, E-ISSN: 2222-6990 @ 2021 HRMARS

Table 1: Respondents Demographic Profile

\begin{tabular}{|c|c|c|}
\hline Mobile Banking Usage & No. & $\%$ \\
\hline \multirow[t]{3}{*}{ Yes } & 397 & 9 \\
\hline & & 3 \\
\hline & & 6 \\
\hline \multirow[t]{2}{*}{ No } & 27 & 6 \\
\hline & & 4 \\
\hline \multicolumn{3}{|l|}{ Gender } \\
\hline \multirow[t]{2}{*}{ Male } & 140 & 3 \\
\hline & & 3 \\
\hline \multirow[t]{2}{*}{ Female } & 284 & 6 \\
\hline & & 7 \\
\hline \multicolumn{3}{|l|}{ Ethnic } \\
\hline \multirow[t]{3}{*}{ Malay } & 143 & 3 \\
\hline & & 3 \\
\hline & & i \\
\hline \multirow[t]{4}{*}{ Chinese } & 247 & 5 \\
\hline & & 8 \\
\hline & & $\dot{2}$ \\
\hline & & 3 \\
\hline \multirow[t]{2}{*}{ Indian } & 25 & 5 \\
\hline & & $\dot{9}$ \\
\hline \multirow[t]{3}{*}{ Others } & 9 & 2 \\
\hline & & . \\
\hline & & 1 \\
\hline \multicolumn{3}{|l|}{ Academic } \\
\hline \multirow[t]{2}{*}{ SPM and below } & 33 & 7 \\
\hline & & 8 \\
\hline \multirow[t]{2}{*}{ Certificate } & 30 & 7 \\
\hline & & $\dot{1}$ \\
\hline \multirow[t]{3}{*}{ Diploma } & 53 & 1 \\
\hline & & 2 \\
\hline & & 5 \\
\hline \multirow[t]{4}{*}{ Bachelor } & 236 & 5 \\
\hline & & 5 \\
\hline & & . \\
\hline & & 7 \\
\hline \multirow[t]{2}{*}{ Master and above } & 72 & 1 \\
\hline & & 7 \\
\hline \multicolumn{3}{|l|}{ Age } \\
\hline $18-24$ & 221 & 5 \\
\hline
\end{tabular}




\begin{tabular}{|c|c|c|}
\hline & & 2 \\
\hline & & 1 \\
\hline $25-34$ & 107 & 2 \\
\hline & & 5 \\
\hline & & i \\
\hline $35-44$ & 62 & 1 \\
\hline & & 4 \\
\hline & & . \\
\hline & & 6 \\
\hline $45-54$ & 20 & 4 \\
\hline & & . \\
\hline & & 7 \\
\hline $55-64$ & 13 & 3 \\
\hline & & i \\
\hline 65 and above & 1 & 0 \\
\hline & & 2 \\
\hline Current Staying Area & & \\
\hline Urban & 352 & 8 \\
\hline & & 3 \\
\hline Rural & 72 & 1 \\
\hline & & 7 \\
\hline Income Level & & \\
\hline RM 2000 or under & 166 & 3 \\
\hline & & 9 \\
\hline & & . \\
\hline & & 2 \\
\hline RM 2001-RM 5000 & 155 & 3 \\
\hline & & 6 \\
\hline & & 6 \\
\hline RM 5001-RM 8000 & 73 & 1 \\
\hline & & 7 \\
\hline & & i \\
\hline RM 8001-RM 10000 & 24 & 5 \\
\hline & & 7 \\
\hline RM 10000 or above & 6 & 1 \\
\hline & & $\dot{4}$ \\
\hline
\end{tabular}

Common method variance used to identify whether data collected are via self- reported questionnaire and, in particular, both the predictor and criterion variables are gain from the same person (Podsakoff, MacKenzi, Lee, \& Podsakoff, 2003). Harman's Single Factor analysis of which Exploratory Factor 
Analysis (EFA) has been used to determine the percentage of variance loading on first factor. The results showed that the largest variance explained by an individual factor was $49.28 \%$. Podsakoff and Organ (1986) claimed that $<50 \%$ means no bias issue in Common Method Variance. Thus, no Common Method Bias has been detected. Reliability test is also being conducted in order to test the relevance of elements, questions or sample item in questionnaire to ensure generation of accurate and valid result. Hence, researcher conducted reliability test and used Cronbach's Alpha to evaluate the reliability of sample item towards the variables measured. According to Nunnally (1978), an alpha value that equal to or greater than 0.70 are considered to be a sufficient condition and it means that these questions in questionnaire possess sufficient reliability. Table below depicted the result of reliability test:

Table 2: Reliability Test

\begin{tabular}{llll}
\hline Variables & $\begin{array}{l}\text { No. of } \\
\text { Item }\end{array}$ & $\begin{array}{l}\text { Item } \\
\text { Deleted }\end{array}$ & $\begin{array}{l}\text { Cronbach Alpha } \\
(\alpha)\end{array}$ \\
\hline $\mathrm{PE}$ & 5 & - & 0.878 \\
$\mathrm{EE}$ & 5 & - & 0.907 \\
$\mathrm{SI}$ & 5 & - & 0.900 \\
$\mathrm{~T}$ & 5 & - & 0.929 \\
$\mathrm{BI}$ & 4 & - & 0.921 \\
\hline
\end{tabular}

All of the measuring items for each variable has high reliability of which a Cronbach's Alpha of 0.7 and above. Thus, no item needs to be deleted. Normality test is used to measure the parametric data in the population to ensure the data collected is normally distributed. Exploratory Data Analysis in SPSS will be used by researcher to run normality test. Distribution of data can be considered normal if the skewness is between the range of -1 and +1 . According to George \& Mallery (2005) and Pallant (2001), the skewness or Kurtosis value between the range of +2 and -2 are considered as acceptable. The result of descriptive analysis and normality test as shown below including mean, standard deviation (SD), Skewness and Kurtosis(K).

According to Table 3, it was shown that data was normally distributed as skewness of each variables are within the acceptable range of -2 and +2 . Researcher found out 25 outliers through normality test. There were 25 outliers in total with 6 extreme outliers for a total respondents of 424 . Then, researcher deleted these 25 outliers which discovered in the boxplot of normality test. After deleting outliers' 
responses, researcher left with 399 respondents as sample in questionnaire distributed to ensure the data collected were normally distributed.

Table 3: Descriptive and Normality Test

\begin{tabular}{lllll}
\hline & Mean & SD & Skew & K \\
\hline PE & 4.35 & 0.65 & -1.910 & 5.349 \\
EE & 4.16 & 0.73 & -1.533 & 3.627 \\
SI & 3.94 & 0.88 & -0.930 & 0.377 \\
T & 3.68 & 0.81 & -0.718 & 1.061 \\
BI & 4.22 & 0.77 & -1.437 & 3.046
\end{tabular}

On the other hand, multiple regression analysis had being conducted by researcher after ensuring data are reliable and normally distributed. Result shown that $R$ value of 0.654 denoted a robust relationship between behavioural intention and 4 independent variables of which performance expectancy (PE), effort expectancy (EE), social influence (SI) and trust $(T)$ as claimed by Cohen in 1988. Furthermore, the coefficient of determination, R2 $=0.421$ stipulated that $42.10 \%$ variance in behavioural intention of mobile banking adoption was being explained by $\mathrm{PE}, \mathrm{EE}, \mathrm{SI}$ and $\mathrm{T}$. The other $45.90 \%$ of the variance that remain unexplained means that there were other potential constructs that would affect adoption of mobile banking in this study.

Table 4 presented the coefficient of four independent variables. PE had the highest standardized coefficient beta value of 0.277 . This indicated that PE contributed highest significance towards BI of MBA. Standardized coefficient beta value also can be denoted as $1 \%$ increment in performance expectancy will resulted in $0.277 \%$ of increment in standard deviation of $\mathrm{BI}$ of $\mathrm{MBA}$ while other variables remain constant. Whereas for the unstandardized coefficient beta, $\mathrm{PE}(\mathrm{B}=0.346)$ also played a main role in the variation of $\mathrm{BI}$ of MBA. To further interpret the unstandardized coefficient beta, every $1 \%$ increment of PE would lead to $0.346 \%$ of increment in behavioural intention of mobile banking adoption in this study. All in all, the regression coefficients reflected an equation that determine the relationship between independent variables ( $\mathrm{PE}, \mathrm{EE}, \mathrm{SI}, \mathrm{T})$ and dependent variable (BI of $\mathrm{MBA})$ will be formed as:

$\mathrm{BI}$ of $\mathrm{MBA}=0.651+0.346 \mathrm{PE}+0.223 \mathrm{EE}+0.092 \mathrm{SI}+0.211 \mathrm{~T}$

Table 4: Coefficient

\begin{tabular}{lllll}
\hline & $\mathrm{B}$ & $\beta$ & $\mathrm{t}$ & $\mathrm{p}$ \\
\hline $\mathrm{C}$ & 0.651 & & 2.905 & 0.004 \\
$\mathrm{PE}$ & 0.346 & 0.277 & 5.625 & 0.000 \\
$\mathrm{EE}$ & 0.223 & 0.202 & 3.879 & 0.000 \\
$\mathrm{SI}$ & 0.092 & 0.117 & 2.722 & 0.007 \\
$\mathrm{~T}$ & 0.211 & 0.238 & 5.222 & 0.000 \\
\hline
\end{tabular}

A $p$ value that greater than 0.05 is considered as not significant while $p$ value that lower than 0.05 is considered significant. Hence, in Table 5, researcher observed that there were no variables have no significance relationship towards the $\mathrm{BI}$ of MBA. All of the variables such that PE $(p=0.000), E E(p=0.000), S I(p=0.007)$ and $T(p=0.000)$ are considered as significant towards $\mathrm{BI}$ of MBA as they had $\mathrm{p}$ value that lower than 0.050 . On the other hand, all of the 
constructs including $P E(B=0.346), E E(B=0.223), S I(B=0.092)$ and $T(B=0.211)$ shown that they had positive relationship with the $\mathrm{BI}$ of MBA as all of their unstandardized betas value were positive.

Table 5: Relationship between IV and DV

\begin{tabular}{llll}
\hline & $\mathrm{p}$ & $\mathrm{B}$ & Relationship \\
\hline $\mathrm{PE}$ & 0.000 & 0.346 & Significance \\
$\mathrm{EE}$ & 0.000 & 0.223 & Significance \\
$\mathrm{SI}$ & 0.007 & 0.092 & Significance \\
$\mathrm{T}$ & 0.000 & 0.211 & Significance \\
\hline
\end{tabular}

Tolerance is the amount of variability in one independent variable that is no explained by other independent variables. Tolerance values less than 0.10 indicate collinearity. In this research, all of the independent variables had high tolerance value. Thus, there were no multicollinearity issue as each variable had a tolerance value that larger than 0.1 , such as performance expectancy (0.598), effort expectancy (0.538), social influence (0.784), trust (0.699). Researcher further access multicollinearity issue by examining Variance Inflation Factor (VIF). VIF is reciprocal of tolerance, it is always greater than or equal to 1 . VIF values that exceed 10 are considered as multicollinearity, while for weaker model, VIF values that above 2.5 are regarded as multicollinearity as well. In accordance with Table 6, researcher discovered that there is no multicollinearity between variables as each variable such that $P E$ (VIF=1.673), EE (VIF=1.858), SI (VIF=1.276) and T (VIF=1.432) had VIF values that lower than both 10 and 2.5 .

Table 6: Multicollinearity

\begin{tabular}{lll}
\hline & Tolerance & VIF \\
\hline PE & 0.598 & 1.673 \\
EE & 0.538 & 1.858 \\
SI & 0.784 & 1.276 \\
$\mathrm{~T}$ & 0.699 & 1.432 \\
\hline
\end{tabular}

\section{Conclusion and Implications}

Result presented above depicted that all of the 4 independent variables (PE, EE, SI, T) had significance relationship towards BI of MBA. This research able to provide a valid reference for banks in Malaysia to implement mobile banking in a more competitive way. Banks might refer to these several factors and further enhance or emphasize them to encourage more mobile banking users. As claimed in the result above, PE was strongest predictors in affecting $\mathrm{BI}$ of MBA. This means that respondents have high concern on whether MBA able to help them to perform their financial services more efficiently. Banks may fasten their process time of financial services provided in current mobile banking system to enhance MBA. Banks might also enrich the financial services provided through mobile banking such as credit card application, loan application and so on to encourage more adoption of mobile banking rather than going to physical bank to perform those financial services.

EE was proven to be significant towards $\mathrm{BI}$ of MBA. This means that respondents in this study also emphasize on effort needed for MBA. Respondents preferred where mobile banking is 
easy to learn, easy to use and easy to access. Lesser effort needed to be exerted for adoption of mobile banking will enhance MBA in Malaysia. Hence, banks should simplify or design the webpage or interface of mobile banking as simple as possible. Banks can consider to collaborate with IOS or Android to have a built-in application in users' phone, so that users can waive off the effort on downloading the apps through application store. With this, mobile banking would be easier to learn and use.

On the other hand, $\mathrm{SI}$ also one of the significant predictors. This indicated that respondents in this survey concern on perception of society towards them in terms of MBA. Malaysia or most of the countries in Asia Pacific tends to have collectivistic culture. This means that Malaysian are tend to work in group and value the relationship as well as opinion of people surroundings. Friends, family members, relatives, siblings, colleagues would be the main influencer in this variable in affecting MBA in Malaysia. Banks are recommended to offer rewards for reference of usage of mobile banking. For example, users of mobile banking can get waive for transaction fees if he or she recommended one friend to use mobile banking. Banks might offer rewards for every user of mobile banking to increase MBA. When more people adopting mobile banking, then the adoption rate of mobile banking will go up automatically due to the collective nature of this society.

Finally, trust also had a significant relationship with BI of MBA. Trust also one of the construct where respondents perceived it is important in order to adopt mobile banking in daily life. As mobile banking is considered as new technology as well as banking method, respondents would have doubt in terms of the functionality and the security of the mobile banking. Banks can tackle on this point in promoting usage of mobile banking. Banks should ensure the services provided are guaranteed in terms of functionality and security. If user found out they able to perform financial related services through mobile banking in a more efficient, effective, secure and safe way, then user would adopt mobile banking as their financial services platform. Thus, banks might update their security system from time to time as well as ensuring mobile banking system able to perform well without broke down in order to enhance the adoption of mobile banking in Malaysia.

\section{Recommendation}

This research only collects opinion from users and non-users of mobile banking. Researcher might widen the categories of sample collected such as banks, bank staff and entrepreneur and categorized them in order to have opinions from different aspects. For recommendation of future research, researcher recommended where more model could be combined to evaluate more factors that potential in affecting MBA. For instance, Task Technology Fit model (TTF) and Initial Trust Model (ITM) are strongly suggested to implement in future research. TTF is the need of a fit between technology features and task requirements that developed by Goodhue and Thompson in 1995. Initial Trust Model (ITM) is a model regarding willingness of an individual to take risks in order to fulfil a need without prior experience, or credible information that established by McKnight et al. in 1998.

\section{References}

Aboelmaged, M., \& Gebba, T. R. (2013). Mobile banking adoption: an examination of technology acceptance model and theory of planned behavior. International Journal of Business Research and Development, 2(1). 
Afshan, S., \& Sharif, A. (2016). Acceptance of mobile banking framework in Pakistan. Telematics and Informatics, 33(2), 370-387.

Schermann, M., \& Merz, M. (2018). User Participation in Information Systems Projects: Necessary But Not Sufficient. In ECIS (p. 103).

Alalwan, A. A., Dwivedi, Y. K., \& Rana, N. P. (2017). Factors influencing adoption of mobile banking by Jordanian bank customers: Extending UTAUT2 with trust. International Journal of Information Management, 37(3), 99-110.

Bank Negara Malaysia. (2018). BNM Mobile Apps. Kuala Lumpur, Malaysia: BNM official website.

Bank Negara Malaysia. (2018). Payment Statistics. Kuala Lumpur, Malaysia. BNM official website.

Baptista, G., \& Oliveira, T. (2015). Understanding mobile banking: The unified theory of acceptance and use of technology combined with cultural moderators. Computers in Human Behavior, 50, 418-430.

Bhatiasevi, V. (2016). An extended UTAUT model to explain the adoption of mobile banking. Information Development, 32(4), 799-814.

Boonsiritomachai, W., \& Pitchayadejanant, K. (2017). Determinants affecting mobile banking adoption by generation $Y$ based on the Unified Theory of Acceptance and Use of Technology Model modified by the Technology Acceptance Model concept. Kasetsart Journal of Social Sciences.

Choudrie, J., Junior, C. O., McKenna, B., \& Richter, S. (2018). Understanding and conceptualising the adoption, use and diffusion of mobile banking in older adults: $\mathrm{A}$ research agenda and conceptual framework. Journal of Business Research, 88, 449-465.

DBS Group Research. (2015). Regional Industry Focus ASEAN Banks. 12 Marina Boulevard, Marina Bay Financial Centre Tower 3 Singapore 018982: DBS Bank Ltd, pp.2-26.

Financial News and Advice in Malaysia. (2017). 2017 Mobile Banking App Review: OCBC Malaysia Banking by OCBC Malaysia I CompareHero.my. [online]. Available at:https://www.comparehero.my/blog/2017-mobile-banking-app-review-ocbcmalaysia-banking-by- ocbc-malaysia.

ING (2016). ING International Survey Mobile Banking 2016. Dutch Central Bank, pp.4-31.

Kishore, S. K., \& Sequeira, A. H. (2016). An empirical investigation on mobile banking service adoption in rural Karnataka. SAGE Open, 6(1), 2158244016633731.

Mahad, M., Mohtar, S., Yusoff, R. Z., \& Othman, A. A. (2015). Factor affecting mobile adoption companies in Malaysia. International Journal of Economics and Financial Issues, 5(1S), 84-91.

Malaquias, R. F., \& Hwang, Y. (2016). An empirical study on trust in mobile banking: A developing country perspective. Computers in Human Behavior, 54, 453-461.

Masrek, M. N., Mohamed, I. S., Daud, N. M., \& Omar, N. (2014). Technology trust and mobile banking satisfaction: a case of Malaysian consumers. Procedia-Social and behavioral sciences, 129, 53-58.

Mei Kei, H. (2018). Department of Statistics Malaysia Official Portal. [online] Dosm.gov.my. Oliveira, T., Faria, M., Thomas, M. A., \& Popovič, A. (2014). Extending the understanding of mobile banking adoption: When UTAUT meets TTF and ITM. International Journal of Information Management, 34(5), 689-703.

Sarfaraz, J. (2017). Unified Theory of Acceptance and Use of Technology (UTAUT) ModelMobile Banking. Journal of Internet Banking and Commerce, 22(3), 1-20. 
Shaikh, A. A., Glavee-Geo, R., \& Karjaluoto, H. (2018). How relevant are risk perceptions, effort, and performance expectancy in mobile banking adoption?. International Journal of E-Business Research (IJEBR), 14(2), 39-60.

Shareef, M. A., Baabdullah, A., Dutta, S., Kumar, V., \& Dwivedi, Y. K. (2018). Consumer adoption of mobile banking services: An empirical examination of factors according to adoption stages. Journal of Retailing and Consumer Services, 43, 54-67.

Shuhidan, S. M., Hamidi, S. R., \& Saleh, I. S. (2017, August). Perceived risk towards mobile banking: a case study of malaysia young adulthood. In IOP Conference Series: Materials Science and Engineering (Vol. 226, No. 1, p. 012115). IOP Publishing.

Singh, S., \& Srivastava, R. K. (2018). Predicting the intention to use mobile banking in India. International Journal of Bank Marketing, 36(2), 357-378.

Tan, E., \& Leby Lau, J. (2016). Behavioural intention to adopt mobile banking among the millennial generation. Young Consumers, 17(1), 18-31.

Venkatesh, V., Morris, M. G., Davis, G. B., \& Davis, F. D. (2003). User acceptance of information technology: Toward a unified view. MIS quarterly, 425-478.

Venkatesh, V., Thong, J. Y., \& Xu, X. (2012). Consumer acceptance and use of information technology: extending the unified theory of acceptance and use of technology. MIS quarterly, 36(1), 157-178.

Veríssimo, J. M. C. (2016). Enablers and restrictors of mobile banking app use: A fuzzy set qualitative comparative analysis (fsQCA). Journal of Business research, 69(11), 54565460.

Deloitte, I. (2017). Predicciones sobre tecnología, medios y telecomunicaciones: https://www2. deloitte.com/content/dam/Deloitte/cr/Documents/technology-mediatelecommunications/estudios. TMT-Predictions-2017-spanish.pdf. 